\title{
PERSPECTIVES OF DEVELOPMENT OF THE PHILOLOGICAL EDUCATION IN UKRAINE
}

\section{Kharchenko Inna ${ }^{1}$}

DOI: https://doi.org/10.30525/978-9934-571-89-3_27

At the beginning of the XXI century, the importance of philological education, as the base of knowledge and determination in the humanities and natural sciences, has increased; the role of language in social relations and social activity has increased as well.

In modern world philological education in Ukraine plays an important social and cultural role. As it is known, the traditional notion of philological education is realized through the training of specialists, mostly teachers, of language and literature for teaching in various educational institutions.

Modern philology combines the traditional sciences such as linguistics, literary criticism and folklore, as its components, as well as a number of scientific disciplines that are characterized by a more complex and modern structure of components. The prime tendency of philological education is its globalization and internationalization.

Challenges in modern development increase the need to modernize the education, the development of new mechanisms for the interaction of education and science with the purpose of updating the content of education on the basis of the achievements of fundamental and applied research, activate the functions of a teacher and student in the context of innovative developments in psychological and pedagogical science direction [1, p. 79].

One of the actual aspects of the development of philological education is the study of the national language. National language is the main resource in comprehension and understanding by all nations and nationalities of centuries-old culture, traditions, customs, peculiarities of world view of every nation.

Polycultural education aims the studyof the cultural and educational values of other cultures on the basis of knowledge of the ethno-cultural group and also on the interaction of all cultures by means of mutual understanding, tolerance and social dialogue [3, p. 4].

Modern world is characterized by the formation of national schools to provide the terminology study. The particular importance in theoretical terminology study belongs to works that determine the patterns of development and the use of professional vocabulary. The applied terminology also performs many functions, its task is to describe, evaluate, edit and arrange new terms.

Social need researches in terminology are connected with the investigation of a term and its function in different texts and situations of professional communication. The use of Ukrainian terms in computer system arose the interest of society [2, p. 57].

\footnotetext{
${ }^{1}$ Sumy National Agrarian University, Ukraine 
Among the scholars, the study of the language of ancient written monuments has become especially relevant. As part of the study of the cultural heritage of Kyivan Rus, philology has enriched with new details in phonetic, lexical, and grammatical features of literary monuments of the ancient Slavic culture. At the same time, contrastive linguistics, which studies the mutual influence of Slavic languages, is successfully developing.

The successes of the philological science provide the development in the priority directions that correspond to global trends. The results of fundamental research is a real resource to ensure the competitiveness of ideas and technology. The achievements of fundamental scientific approaches, in turn, serve as an impetus for the development of applied researches.

It was generalized that the modernization of philological education, the introduction of innovative technology, intellectualization of labor and the achievement of the state's competitiveness are based on the level of development of fundamental science, its interaction with applied researches and the formation of the system and mechanisms for the implementation of research results.

The priority directions of further research are the study of the issues of modernization of the system of philological education in Ukraine and the study of the best achievements in philological science of the European Union countries in order to integrate the national system of education into the European educational space.

\section{References:}

1. Bereziuk O., Smoliar V. (2014). Shliakhy modernizatsii osvitnoi systemy Ukrainy [The Ways of modernization of the educational system of Ukraine]. Tendentsii modernizatsii natsionalnykh osvitnikh system: zbirnyk naukovykh prats. Zhytomyr: Vyd-vo ZhDU im. I. Franka, pp. 78-81.

2. Desiatov T. (2015). Yevropeiski tendentsii ta ukrainski perspektyvy rozvytku teorii i praktyky osvity doroslykh [The European Trends and the Ukrainian Perspectives of the Development of the Theory and Practice of Adult Education]. Yevropeiskyi Soiuz - Ukraina: osvita doroslykh: zbirnyk materialiv forumu do mizhnarodnykh dniv osvity doroslykh v Ukraini (Kyiv, November 4-6, 2014). Nizhyn: Vydavets PP Lysenko M.M, pp. 55-60.

3. Poliakov M. V. (2016). Movna polityka suchasnoho universytetu [Language politics of the modern university]. Aktualni problemy filolohichnoi nauky ta pedahohichnoi praktyky: materialy VI Vseukrainskoi naukovo-praktychnoi konferentsii (Dnipro, December 1-2, 2016) Dnipro, pp. 3-5. 